\title{
FAKTOR - FAKTOR YANG BERHUBUNGAN DENGAN PEMAKAIAN KONTRASEPSI IUD PADA IBU USIA REPRODUKTIF
}

\author{
Nurul Lidya ${ }^{1}$, Vera Suzana ${ }^{1}$, Siti Rahmadani ${ }^{1}$ \\ ${ }^{1}$ Jurusan Kebidanan, Politeknik Kesehatan Kemenkes Jakarta I, Indonesia
}

\begin{tabular}{l}
\hline Info Artikel \\
\hline Genesis Naskah: \\
Submissions: $29-10-2020$ \\
Revised: $2-11-2020$ \\
Accepted: $14-11-2020$
\end{tabular}

Kata Kunci:

Kontrasepsi IUD,

Pekerjaan, Pengetahuan,

Usia reproduktif.
Abstrak

Menurut Dinkes Provinsi DKI Jakarta (2012), angka kelahiran hidup yaitu 111.460 orang. Jumlah PUS di Kecamatan Pasar Minggu, Jakarta Selatan sebanyak 955.269 orang, yang sudah menjadi akseptor adalah 852.278 orang. Pemakaian kontrasepsi IUD yaitu sebanyak 40.359 (5,8\%). Tujuan penelitian ini untuk mengetahui faktorfaktor yang berhubungan dengan pemakaian kontrasepsi IUD pada ibu usia reproduktif di RW 09 Ragunan Pasar Minggu Jakarta Selatan tahun 2018. Jenis penelitian adalah Cross Sectional. Penelitian ini dilakukan pada ibu usia reproduktif di RW 09 Ragunan Pasar Minggu Jakarta Selatan tahun 2018 dengan sampel yaitu ibu usia reproduktif sebanyak 108. Analisa data terdiri dari univariat dan bivariate. Hasil dari penelitian menunjukkan ada hubungan pekerjaan dengan pemakaian kontrasepsi IUD pada ibu usia reproduktif $(p=0,003)$. Terdapat hubungan pengetahuan dengan pemakaian kontrasepsi IUD pada ibu usia reproduktif $(p=$ 0,001). Simpulan penelitian ini, terdapat hubungan yang bermakna antara pekerjaan dan pengetahuan dengan pemakaian kontrasepsi IUD. Saran pada penelitian ini bagi tenaga kesehatan untuk lebih meningkatkan pengetahuan melalui penyuluhan kesehatan kepada ibu yang tidak bekerja sehingga meningkatkan cakupan akseptor KB IUD dan melakukan promosi pada pemakaian kontrasepsi secara gratis.

FACTORS RELATED TO THE USE OF IUD CONTRACEPTION ON THE REPRODUCTION OF MOTHER'S

Keywords:
IUD contraception,
Knowledge, Rreproduktif
age, Occupation

age, Occupation

\begin{abstract}
According to the DKI Jakarta Provincial Health Office (2012), the live birth rate is 111,460 people. The number of PUS in Pasar Minggu District, South Jakarta is 955,269 people, who have become acceptors are 852,278 people. The use of IUD contraception was 40,359 (5.8\%). The purpose of this study was to determine the factors associated with the use of IUD contraceptives in reproduktif age mothers at RW 09 Ragunan Pasar Minggu Jakarta Selatan in 2018. This type of research is cross sectional. This research was conducted on reproduktif age mothers at $R W 09$ Ragunan Pasar Minggu Jakarta Selatan in 2018 with a sample of 108 reproduktif age mothers. Data analysis consisted of univariate and bivariate. The results of the study showed that there was a relationship between work and the use of IUD contraception in mothers of reproduktif age $(p=0.003)$. There is a knowledge relationship with the use of IUD contraception in mothers of reproduktif age ( $p=$ 0.001). The conclusion of this study, there is a significant relationship between work and knowledge with the use of IUD contraception. Suggestions in this study for health workers to further increase knowledge through health education to mothers who do not work so as to increase the coverage of IUD family planning acceptors and promote the use of free contraceptives.
\end{abstract}


Lidya/JMSWH, Volume1, Nomor 1 tahun 2020: 21-26

\section{Korespondensi Penulis:}

Nurul Lidya

Jl Wijayakusuma Raya No. 47 Cilandak Jakarta Selatan, Indonesia

nurullidya03@gmail.com

Journal of Midwifery Science and Women's Health

Volume 1, Nomor 1 Tahun 2020 


\section{PENDAHULUAN}

Pengendalian jumlah penduduk di Indonesia, dilakukan melalui pendekatan upaya pendewasaan usia kawin, penundaan mempunyai anak pertama, penjarangan kelahiran dan mengakhiri kehamilan. Di sisi lain upaya pengendalian angka kelahiran (fertilitas) penduduk dilakukan melalui memaksimalkan akses dan kualitas pelayanan Keluarga Berencana/KB (BKKBN, 2017). Berbagai upaya pemerintah telah dilakukan untuk peningkatan penggunaan IUD diantaranya adalah dengan adanya kebijakan pemasangan IUD secara gratis kepada pasangan usia subur, penyediaan alat kontrasepsi, tersedianya dukungan anggaran untuk AKDR serta tersedianya dana pelatihan medis tekhnis bagi provider (BKKBN, 2013).

Pasangan Usia Subur mengalami kesulitan di dalam menentukan pilihan jenis kontrasepsi. Hal ini tidak hanya karena terbatasnya metode yang tersedia, tetapi juga oleh ketidaktahuan mereka tentang persyaratan dan keamanan metode kontrasepsi tersebut (Saifudin A, 2019). Berbagai faktor harus dipertimbangkan, diantaranya usia, paritas, usia anak terkecil, pasangan, biaya, kepercayaan dan budaya, tingkat pendidikan, tingkat pengetahuan, status wanita.

Dilihat dari jumlah akseptor masing masing alat kontrasepsi, diketahui jumlah pengguna AKDR sangat sedikit di banding alat kontrasepsi lain yang lazim digunakan. Namun dalam kenyataannya tingkat keakuratan AKDR lebih tinggi, karena bisa digunakan dalam waktu yang cukup lama dengan efek samping yang minimal (Suratun, 2011). Tujuan penelitian ini untuk mengetahui faktor-faktor yang berhubungan dengan pemakaian kontrasepsi IUD pada ibu usia reproduktif di RW 09 Ragunan Pasar Minggu Jakarta Selatan tahun 2018.

\section{METODE}

Jenis penelitian ini merupakan penelitian cross sectional. Sampel untuk penelitian ini adalah wanita usia subur yang berada di wilayah Pasar Minggu. Teknik pengambilan sampel dalam penelitian ini menggunakan metode purposive sampling untuk memperoleh data peneliti yaitu menemui subjek penelitian yaitu ibu usia reproduktif di RW 09 Ragunan
Pasar Minggu Jakarta Selatan yang berjumlah 108 responden. Analisa data pada penelitian ini terdiri dari univariat yaitu distribusi frekuensi dan proporsi sedangkan bivariat menggunakan chi square.

\section{HASIL}

Penelitian ini dilaksanakan di RW 09 Ragunan Pasar Minggu Jakarta Selatan Tahun 2018. waktu pelaksanaan penelitian pada bulan Juli s.d. November 2018. Penulis melakukan penelitian dengan jenis penelitian analitik dengan desain cross sectional.

1. Analisis Univariat

Tabel 1. Distribusi Frekuensi Responden Berdasarkan Karakteristik di RW 09 Ragunan Pasar Minggu Jakarta Selatan Tahun 2018

\begin{tabular}{|c|c|c|}
\hline Karakteristik & $\mathrm{n}$ & $\%$ \\
\hline $\begin{array}{l}\text { 1. Umur } \\
\cdot<20 \text { thn } \\
\cdot 20-35 \text { tahun } \\
\cdot>35 \text { tahun }\end{array}$ & $\begin{array}{l}20 \\
59 \\
29\end{array}$ & $\begin{array}{l}18,5 \\
54,6 \\
26,9\end{array}$ \\
\hline $\begin{array}{l}\text { 2. Paritas } \\
\text { - Primipara } \\
\text { - Multipara } \\
\text { - Grandemultipara }\end{array}$ & $\begin{array}{c}54 \\
48 \\
6\end{array}$ & $\begin{array}{c}50 \\
44,4 \\
5,6\end{array}$ \\
\hline $\begin{array}{l}\text { 3. Pendidikan } \\
\text { - Rendah } \\
\text { - Menengah } \\
\text { - Tinggi }\end{array}$ & $\begin{array}{l}31 \\
64 \\
13\end{array}$ & $\begin{array}{l}28,5 \\
59,2 \\
12,3\end{array}$ \\
\hline $\begin{array}{l}\text { 4. Pekerjaan } \\
\text { - Bekerja } \\
\text { - Tidak Bekerja }\end{array}$ & $\begin{array}{l}37 \\
71\end{array}$ & $\begin{array}{l}34,2 \\
65,8\end{array}$ \\
\hline $\begin{array}{l}\text { 5. Pengetahuan } \\
\text { - Kurang } \\
\text { - Cukup } \\
\text { - Kurang }\end{array}$ & $\begin{array}{l}38 \\
45 \\
25\end{array}$ & $\begin{array}{l}35,2 \\
41,6 \\
23,2\end{array}$ \\
\hline $\begin{array}{l}\text { 6. Pemakaian IUD } \\
\text { - Iya } \\
\text { - Tidak }\end{array}$ & $\begin{array}{l}30 \\
78\end{array}$ & $\begin{array}{l}27,5 \\
72,5\end{array}$ \\
\hline
\end{tabular}

Tabel 1, menunjukkan bahwa dari 108 responden umur yang tertinggi yaitu 20-35 tahun sebanyak 59 orang $(54,6 \%)$, sedangkan paritas paling banyak yaitu primipara 54 orang $(50 \%)$, pendidikan paling tinggi yaitu menengah 64 orang $(59,2 \%)$, responden paling banyak tidak bekerja sebanyak 71 orang 
$(65,8 \%)$, tingkat pengetahuan responden paling banyak yaitu cukup 45 orang $(41,6 \%)$ dan responden paling banyak tidak memakai IUD yaitu 78 orang $(72,5 \%)$

2. Analisis Bivariat

Tabel 2. Pemakaian Kontrasepsi IUD

Berdasarkan Karakteristik Responden di RW

09 Ragunan Pasar Minggu Jakarta Selatan Tahun 2018

\begin{tabular}{|c|c|c|c|}
\hline \multirow{2}{*}{ Karakteristik } & \multicolumn{2}{|c|}{ Pemakai Kontrasepsi IUD } & \multirow{2}{*}{$\begin{array}{c}\text { Nilai } \\
\mathrm{P}\end{array}$} \\
\hline & Iya & Tidak & \\
\hline $\begin{array}{l}\text { 1.Umur } \\
-<20 \text { tahun } \\
-20 \quad-35 \\
\quad \text { tahun } \\
\text { - }>35 \text { tahun }\end{array}$ & $\begin{array}{l}7(23,3 \%) \\
17(56,7 \%) \\
6(20 \%)\end{array}$ & $\begin{array}{l}13(16,6 \%) \\
42(53,9 \%) \\
23(29,5 \%)\end{array}$ & 0,467 \\
\hline $\begin{array}{l}\text { 2.Paritas } \\
\text { - Primipara } \\
\text { - Multipara } \\
\text { - Grande } \\
\text { multi }\end{array}$ & $\begin{array}{l}14(46,7 \%) \\
12(40 \%) \\
4(13,3 \%)\end{array}$ & $\begin{array}{l}40(51,3 \%) \\
36(46,1 \%) \\
2(2,6 \%)\end{array}$ & 1,4561 \\
\hline $\begin{array}{l}\text { 3.Pendidikan } \\
\text { - Rendah } \\
\text { - Menengah } \\
\text { - Tinggi }\end{array}$ & $\begin{array}{l}9(30 \%) \\
13(43,4 \%) \\
8(26,7 \%)\end{array}$ & $\begin{array}{l}22(28,2 \%) \\
51(65,3 \%) \\
5(6,5 \%)\end{array}$ & 3,465 \\
\hline $\begin{array}{l}\text { 4.Pekerjaan } \\
\text { - Bekerja } \\
\text { - Tidak } \\
\text { Bekerja }\end{array}$ & $\begin{array}{l}16(53,3 \%) \\
14(46,6 \%)\end{array}$ & $\begin{array}{l}21(27 \%) \\
57(73 \%)\end{array}$ & 0,003 \\
\hline $\begin{array}{l}\text { 5.Pengetahuan } \\
\text { - Kurang } \\
\text { - Cukup } \\
\text { - Baik }\end{array}$ & $\begin{array}{l}3(10 \%) \\
12(40 \%) \\
15(50 \%)\end{array}$ & $\begin{array}{l}35(45 \%) \\
33(42,3 \%) \\
10(12,7 \%)\end{array}$ & 0,001 \\
\hline
\end{tabular}

Tabel 2 menunjukkan bahwa karakteristik pada variable pekerjaan dan pengetahuan menunjukkan nilai $\mathrm{p}<0,05$, artinya terdapat hubungan yang bermakna antara pekerjaan dan pengetahuan dengan pemakaian kontrasepsi IUD pada ibu usia reproduksi, sedangkan umur, paritas dan Pendidikan memiliki nilai $\mathrm{p}>0,05$ artinya tidak ada hubungan yang bermakna antara umur, paritas dan pendidikan dengan Pemakaian Kontrasepsi IUD pada ibu usia reproduktif .

\section{PEMBAHASAN}

1. Hubungan Antara Usia dengan Pemakaian Kontrasepsi IUD

Berdasarkan hasil penelitian didapat tidak ada hubungan yang bermakna antara usia ibu dengan pemakaian kontrasepsi IUD. Dari hasil penelitian Marlina (2017) menyatakan ibu yang tidak memakai AKDR lebih banyak pada ibu berusia $>35$ tahun dibandingkan dengan ibu yang berusia <35 tahun (Marlina, 2017).

Menurut asumsi penulis dari hasil penelitian yang dilakukan menyimpulkan tidak ada hubungannya antara usia dengan pemakai kontrasepsi IUD. Sedangkan pada penelitian ini penulis menemukan responden yang memilih menggunakan alat kontrasepsi dalam rahim pada usia > 35 tahun. Dikarenakan pada usia > 35 tahun pengetahuan, pengalaman, dan keaktifannya tentang penggunaan alat kontrasepsi sudah cukup baik. Tetapi pada responden yang berusia $<20$ tahun karena rasa ingin tahu tentang alat kontrasepsi dalam rahim (AKDR) masih kurang mendapat respon positif. Hal ini yang menyebabkan penggunaan alat kontrasepsi jangka panjang masih kurang diminati.

2. Hubungan Antara Paritas dengan Pemakaian Kontrasepsi IUD

Berdasarkan hasil penelitian ini tidak terdapat hubungan yang bermakna antara paritas ibu dengan pemakaian kontrasepsi IUD. Hasil penelitian ini tidak sama dengan teori dan beberapa penelitian yang ada. Seseorang yang berparitas lebih dari satu sudah seharusnya menjadi akseptor KB untuk mengatur atau menjarangkan kehamilannya, tetapi dewasa ini banyak akseptor KB yang masih mengalami kesulitan dalam menentukan pilihannya (Wiknjosastro, 2014). Hasil penelitian yang dilakukan oleh Fitri (2012), didapatkan tidak ada hubungan antara jumlah anak dengan pemilihan kontrasepsi IUD baik responden yang mempunyai anak banyak maupun responden yang mempunyai anak sedikit. Oleh karena itu jumlah anak tidak berperan penting dalam memutuskan memilih menggunakan alat kontrasepsi IUD (Fitri R, 2012).

Menurut asumsi penulis dari hasil penelitian yang didapat tidak ada hubungannya paritas dengan pemakai kontrasepsi IUD. Hal ini mungkin karena keluarga berencana sebenarnya bukan untuk menghentikan kehamilan, akan tetapi untuk menunda serta mengatur jarak kehamilan. Pada kenyataannya ini bertentangan dengan motto keluarga 
berencana saat ini yaitu 2 anak lebih baik, sehingga diharapkan dapat tercipta keluarga yang berkualitas. Selain itu kemungkinan dikarenakan kurangnya informasi tentang alat kontrasepsi yang efektif dan jangka panjang seperti IUD, sehingga responden masih banyak yang menggunakan alat kontrasepsi seperti pil dan suntik.

\section{Hubungan Antara Pendidikan dengan Pemakaian Kontrasepsi IUD \\ Berdasarkan hasil penelitian didapatkan} tidak ada hubungan yang bermakna antara pendidikan ibu dengan pemakaian kontrasepsi IUD. Hal ini berbeda dengan hasil penelitian Putriningrum (2012), pendidikan adalah usaha sadar untuk menyiapkan peserta didik melalui kegiatan bimbingan, pengajaran dan Latihan bagi peranannya masa yang akan datang, dapat juga Pendidikan diartikan sebagai proses memanusiakan manusia secara manusiawi, disesuaikan dengan perkembangan situasi dan kondisi sosial (Putriningrum, 2012).

Menurut penelitian tentang faktor-faktor yang mempengaruhi penggunaan alat kontrasepsi IUD di Klinik Mulia Kasih Donohudan Ngemplak Boyolali diperoleh hasil bahwa terdapat hubungan yang signifikan antara pendidikan ibu terhadap penggunaan IUD. Dari hasil peneltian dapat dilihat bahwa terdapat hubungan antara tingkat pendidikan dengan penggunaan alat kontrasepsi IUD (Septiani, 2011). Menurut asumsi penulis dari hasil penelitian yang didapat tidak ada hubungannya pendidikan dengan pemakai kontrasepsi IUD, karena pada penelitian ini responden yang pendidikan rendah dan tinggi lebih sedikit dibanding yang pendidikan menengah.

\section{Hubungan Antara Pekerjaan dengan Pemakaian Kontrasepsi IUD}

Berdasarkan penelitian didapatkan ada hubungan yang bermakna antara pekerjaan ibu dengan pemakaian kontrasepsi IUD. Hasil penelitian ini sama seperti hasil penelitian dari Septiani (2011), ibu yang bekerja akan bertemu dan berinteraksi dengan banyak orang dari segala bidang sehingga memiliki pengalaman dan pengetahuan yang lebih baik daripada ibu yang tidak bekerja. Menurut Notoatmodjo (2014), makin tinggi pengetahuan seseorang maka makin mudah seseorang memperoleh pekerjaan dan dapat menghasilkan keuntungan yang lebih besar (Notoatmodjo, 2014).

Menurut asumsi penulis dari hasil penelitian yang didapat ada hubungannya pekerjaan dengan pemakai kontrasepsi IUD. Karena seseorang yang bekerja cenderung lebih mudah menerima informasi dari berbagai sumber seperti dari teman kerja, internet, dan media lainnya sehingga pengetahuan ibu lebih baik tentang Kontrasepsi IUD.

5. Hubungan Antara Pengetahuan dengan Pemakaian Kontrasepsi IUD

Berdasarkan penelitian ini didapatkan ada hubungan yang bermakna antara pengetahuan ibu dengan pemakaian kontrasepsi IUD. Hasil penelitian sama seperti yang dilakukan oleh Putri (2011), menunjukkan hasil bahwa responden yang memiliki pengetahuan kurang cenderung tidak memilih untuk menggunakan metode KB IUD, hal tersebut menyatakan bahwa ada pengaruh pengetahuan akseptor KB terhadap pemilihan kontrasepsi IUD dimana semakin kurang pengetahuan akseptor $\mathrm{KB}$ maka semakin kecil kemungkinan untuk menggunakan IUD dan begitu juga sebaliknya (Putri, 2011). Sama seperti yang dijelaskan oleh Notoatmodjo (2014), pengetahuan merupakan kemampuan seseorang yang memiliki pengaruh terhadap tindakan yang dilakukan seseorang, pengetahuan atau intelektual juga mempengaruhi pola pikir atau cara berpikir seseorang, tinggi rendahnya tingkat pengetahuan seseorang akan mempengaruhi tindakan seseorang dalam melakukan suatu tindakan khususnya di bidang kesehatan terutama dalam hal mencari pelayanan kontrasepsi untuk meningkatkan kesejahteraan keluarga dengan cara mencegah dan menjarangkan kehamilan (Notoatmodjo, 2014).

Menurut asumsi penulis dari hasil penelitian yang didapat ada hubungannya 
Lidya/JMSWH, Volume1, Nomor 1 tahun 2020: 21-26

pengetahuan dengan pemakai kontrasepsi IUD. Kurangnya pengetahuan ibu tentang IUD sehingga menyebabkan rendahnya jumlah pengguna IUD membuktikan bahwa IUD sebagai metode $\mathrm{KB}$ yang efektif masih merupakan suatu metode KB yang awam di masyarakat sehingga mereka tidak berani memilih metode KB IUD dan menunjukkan pula bahwa ini merupakan suatu masalah serius yang belum berhasil tertuntaskan di masyarakat.

\section{KESIMPULAN}

Berdasarkan hasil penelitian dapat disimpulkan bahwa terdapat hubungan yang bermakna antara variabel pekerjaan dan pengetahuan dengan pemakaian kontrasepsi IUD pada ibu usia reproduktif. Tidak ada hubungan yang bermakna antara umur, paritas dan pendidikan dengan pemakaian kontrasepsi IUD.

Saran pada penelitian ini bagi tenaga kesehatan untuk lebih meningkatkan pengetahuan melalui penyuluhan kesehatan kepada ibu yang tidak bekerja sehingga meningkatkan cakupan akseptor KB IUD dan melakukan promosi pada pemakaian kontrasepsi secara gratis.

\section{DAFTAR PUSTAKA}

BKKBN. (2017). Laporan Akuntabilitas Kinerja Instansi Pemerintah 2017. https://www.bkkbn.go.id/pocontent/uploads/lakip-BKKBN-2017.pdf

Fitri R. (2012). Hubungan faktor predisposisi, faktor pemungkin dan faktor penguat dengan pemilihan kontrasepsi IUD di wilayah kerja Puskesmas Pagaran Tapah Darussalam Kabupaten Rokan Hulu Provinsi RIAU tahun 2012. UI Depok, Jakarta.

Marlina, L. S. (2017). Faktor-faktor yang Mempengaruhi Akseptor KB dalam Pemakaian Kontrasepsi Dalam Rahim (AKDR) di Puskesmas Tegal Sari III
Medan Sumatera Utara Tahun 2017.

Universitas Sumetera Utara.

Notoatmodjo. (2014). Promosi Kesehatan dan Ilmu Perilaku. Rineka Cipta.

Putri, E. S. . (2011). Faktor-faktor Yang Berhubungan Dengan Pemilihan Alat Kontrasepsi Dalam Rahim Pada Akseptor Keluarga Berencana Di Desa Seuneubok Rawa Kecamatan Peusangan Kabupaten Bireun. Sekolah Tinggi Ilmu Kesehatan U“e Budiyah Indonesia.

Putriningrum, R. (2012). Faktor-faktor yang Mempengaruhi Ibu dalam Pemilihan Kontrasepsi KB Suntik di BPS. Ruvina Surakarta. Jurnal Kesehatan Kusuma Husada.

Saifudin A. (2019). Buku Panduan Praktis Pelayanan Kontrasepsi. Yayasan Bina Pustaka Sarwono Prawirohardjo.

Septiani, H. (2011). Faktor-Faktor Yang Mempengaruhi Penggunaan Alat Kontrasepsi Iud Di Klinik Mulia Kasih Donohudan Ngemplak Boyolali.

Suratun. (2011). Pelayanan Keluarga Berencana dan Pelayanan Kontrasepsi. Trans Info Media.

Wiknjosastro. (2014). Ilmu Kebidanan (3rd ed.). Yayasan Bina Pustaka. 